\title{
Response Of Mice Tissues To Intranasal Bacterial Lysate Vaccination: Immunohistopathological Study
}

\author{
Hanaa A. Mansour \\ Pharmacology department (Medical microbiology and immunology unit), National \\ Organization for Drug Control And Research (NODCAR), Giza, Egypt
}

\begin{abstract}
Effective protection against pathogenic bacteria requires both mucosal and systemic immune responses. Intranasal administration of antigens induces these responses. The protective effect of intranasal immunization with different formalin-inactivated bacterial lysates in albino mice was evaluated. This study used formalin inactivated lysate of each of the following Escherichia coli , Pseudomonas aeroginosa ,Salmonella typhi, Shigella flexeneri, Staphylococcus aureus, Bacillus subtilis and mixed bacterial lysates. The lysate was administered intranasally $(5 \mu \mathrm{l} /$ nostril) once daily for seven consecutive days. The results of this study recorded some changes in peripheral blood total and differential leucocytic counts , peritoneal fluid and bone marrow lymphocytic percentages. Spleen and thymus weight changes were reported under the effect of Salmonella typhi lysate, Shigella flexeneri lysate and Staph. aureus lysate. The level of immunoglobulin $\mathrm{G}$ (Ig G) was assessed in serum, bronchial lavage and nasal bed harvest. The levels of Ig $\mathrm{G}$ were significantly elevated in the three determinants, suggesting an efficient immunostimulatory effect of bacterial lysates. Some of these levels were exceeding 2-3 folds of that of the control group. Histopathological studies recorded changes in some reticuloendothelial system organs including the liver, spleen and thymus gland, besides, some changes were also observed in the lung and bronchi under the effect of intranasal vaccination. This study supports the immunoprotective effect of intranasal vaccination, using bacterial lysates.
\end{abstract}

\section{Introduction}

Effective protection against respiratory tract pathogens requires both mucosal and systemic immune responses. Intranasal administration of antigens induces these responses. Intranasal immunization is more effective than oral immunization, as it generates an earlier and stronger mucosal immune response (Hirabayashi et al., 1990). Inactivated whole bacterial cell suspensions are probably the most common type of vaccine used in domestic animals. These vaccines proved to be extremely effective and safe to use even in young or pregnant animals (Bey et al., 1997). Havlasova et al. (2002), have detected more than 80 different immunorelevant antigens came from whole cell bacterial lysate of Francisella tularenis. Such antigens are responsible for immune-omodulator, immunostimulant activities of whole cell bacterial lysates.

Bacterial vaccines can be applied effectively through the intranasal route (Orr et al., 1993 and Ambrosino, 1996). Bonenfant et al. (2001) mentioned that the ability for increasing systemic and mucosal responses may be of great importance for the development of an efficient vaccine. Furthermore, the intranasal route requires less antigen than the oral route because there is much less proteolytic activity in the nasal cavity. This route effectively promotes the production of both systemic and mucosal immune responses to the antigen (Wu and Russell, 1997). DiTommaso et al. (1996) and Partidos et al. (1999), showed that bacterial enterotoxins act as appropriate mucosal adjuvants 
following oral and intranasal immunization with various antigens that trigger local and systemic immune responses. These adjuvants have also been used with bacterial antigen and protect against infection with Helicobacter pylori after oral vaccination (Kim et al., 1999) and intragastric vaccination (Marchetti et al., 1998) .

Gawlik and Danek (1999), mentioned that bacterial lysates act as immunomodulators- immunoprophylactics in chronic respiratory diseases. Rutishauser et al. (1998) and Grevers et al. (2000) used polyvalent bacterial lysates in patients with recurrent respiratory tract infections where an oral immunomodulator consisting of the antigens of seven bacteria commonly involved in respiratory tract infections has been developed for the induction of specific and non-specific immune responses of the mucosa associated lymphoid tissue. Jakobsen et al. (1999) showed that the intranasal immunization with Streptococcus pneumo-niae polysaccharide conjugate vaccine could protect mice against invasive pneumococcal infections. The use of nasal delivery of an acellular Bordetella pertussis vaccine, could effectively protect against Bordetella pertussis infection through the activation of Th1 and Th2 cells. Greenbaum et al. (2004) showed that the levels of mucosal Ig A and serum Ig A and Ig G were elevated in response to intranasal administration of inactivated anti- influenza vaccine.

This study aimed to evaluate the immunoprotective effect of daily intranasal lysate vaccination for seven consecutive days using lysates of each of the following: Escherichia coli, Psudomonas aeroginosa, Salmonella typhi, Shigella flexeneri, Staphylococcus aureus and mixed bacterial lysates.

\section{Material And Methods}

\section{Bacteria:}

1. Escherichia coli (CAIM-1357).

2. Pseudomonas aeroginosa ( clinicaly isolated).

3. Staphylococcus aureus (CAIM-1352).

4. Salmonella typhi.
5. Shigella sp. (NMRO).

6. Bacillus subtilis (CAIM-

1007).

Bacterial strains used in this study were obtained from the Microbiology Department in NODCAR.

\section{Animals:}

Eighty male albino mice weighing 18$25 \mathrm{gm}$ each were used in the present study. The animals were obtained from the animal house of NODCAR. The animals were divided into the following groups, control, placebo and intranasal vaccinated .

\section{Intranasal vaccinated group:}

Bacterial lysate vaccinated group which recived Esch. coli lysate, Ps. aeroginosa lysate, Staph. aureus lysate and mixed bacterial lysates (Corthesy- Theulaz et al., 1998 and Bonenfant et al., 2001). Each animal received $5 \mu \mathrm{l}$ of the vaccine in each nostril, once daily that was repeated for seven consecutive days (Ruedl et al., 1994 and Bennet- Guerrero et al., 2000).

\section{Bacterial lysate preparation :}

A 24 hours bacterial growth of Escherichia coli, Pseudomonas aeroginosa, Salmonella typhi, Staphylococcus aureus and Bacillus subtilis that had viable counts $2.72 \times 10^{8}, 7.56 \times 10^{8}, 13.91 \times 10^{8}, 7.33 \times 10^{8}$ and $2.91 \times 10^{8} \mathrm{CFU} / \mathrm{ml}$ respectively was used to prepare the bacterial lysate used in this study. A volume of $25 \mathrm{ml}$ of the 24 hours bacterial growth was lysed using high speed $4000 \mathrm{rpm}$ homogenizer [ variable GKH- GT MOTOR control- Glas- Col (USA) ]. $1 / 100 \mathrm{v} / \mathrm{v}$ of $10 \%$ formalin was added (Okamoto et al., 2004) . Then a subculture of the lysates on nutrient agar (Oxoid) were observed for 24 hours to ensure that the bacterial lysates did not include any viable bacteria (Hugo and Russel, 1993 and Raghavan et al., 2002). Mixed bacterial lysates were prepared from equal volumes of the different bacterial lysates used in this study (Ruah et al., 2001).

\section{Nasal bed harvest :}

The nasal-associated lymphoid tissue were harvested under sterile conditions 
using an automatic cell harvester, high speed homogenizer (Variable GKH-GT MOTOR control- Glass- Col. USA). One gram of the dissected nasal bed was harvested in $1 \mathrm{ml}$ of phosphate buffer saline ( PBS ), then centrifuged aseptically at 4000 rpm for 15 mins. to separate the supernatant that was kept frozen until assayed for estimating the level of Ig G (Bonenfant et al, 2001).

\section{Bronchial lavage :}

Lung washes were obtained by performing bronchial lavage where repeated flushing and aspiration of $1 \mathrm{ml}$ of phosphate buffer saline (PBS) was done under sterile conditions. The wash was centrifuged at $4000 \mathrm{rpm}$ for $15 \mathrm{mins}$. to remove any cell debris. The supernatant was aspirated and kept frozen until assayed for estimating the level of Ig G (Williamson et al., 2000 and Bonenfant et al., 2001).

\section{Immunoglobulins assay :}

Serum was obtained from control animals and bacterial lysates treated animals. Serum was divided into aliquots and stored in the freezer until processed. Immunoglobulins $\mathbf{G}$ and $\mathbf{M}$ assays were done using [ Mouse Immunoglobulin 'LL' NANORID- BIND A RID- NANORID PRODUCTS- immundiff-usion plates which were supplied by THE BINDING SITE LIMITED Co. UK]. The precipitation rings were measured to an accuracy of 0.1 $\mathrm{mm}$. The assay results were obtained from the calibration table values given by the manufacturer (Fahey and Mc Kelvey, 1965 and Sadeq et al., 1992).

\section{Haematology assays:}

About $0.25 \mathrm{ml}$ blood samples were drawn by capillary tubes from the retroorbital plexus from each mouse, being added to EDTA for peripheral blood total leucocytic count and differntial leucocytic count. Direct smears were withdrawn from the peritoneal fluid for peritoneal fluid total and differential leucocytic counts. Bone marrow smears that were obtained from the femur bone were spreaded for bone marrow lymphocytic count. Leishman stain was used for the different leucocytic counts.

\section{Physiological parameters:}

The total body weight (T) of each animal was recorded, followed by determining the liver(L), spleen(S) and thymus (Th) weights and the $(\mathrm{L}+\mathrm{S}+\mathrm{Th}) / \mathrm{T}$ ratio was determined.

\section{Histopathological examination :}

The liver, spleen, thymus gland, lung and tracheae were collected soon after slaughter and fixed in 10\% formalin, blocked in paraffin wax, cut in sections 5 $\mu \mathrm{m}$ and stained with haematoxyline and Eosin (H\&E) for microscopic examination.

The results were statistically evaluated using the student $\mathrm{t}$ - test where the significance of the differences between treated and respective control groups was analysed (Goldstein, 1964) .

\section{Results}

The results demonstrated in table (1) cleared that bacterial lysate daily vaccinated animal groups showed increased total leucocytic count except in case of Salmonella typhi lysate. This leucocytic response was significant on the use of mixed bacterial lysates at $\mathrm{P}<0.001$, that was associated with significant increase of neutrophilic count at $\mathrm{P}<0.05$. Escherichia coli lysate caused significant increase of neutrophilic count that was associated with a significant drop of lymphocytic count.

Table (2) showed that Salmonella typhi, Shigella flexneri, Pseudomonas aeroginosa and mixed bacterial lysates intranasal vaccination caused a significant drop of peritoneal fluid neutrophilic counts that were associated with a significant lymphocytic response and non- significant drop in monocytic and eosinophilic counts

Table (3) showed that mixed bacterial lysates caused an increase of bone marrow lymphocytic percentage in intranasally vaccinated animals, while Salmonella typhi lysate intranasal vaccination induced a significant drop of bone marrow lymphocytic percentage at $\mathrm{P}<0.001$. 
Table (4) illustrated a splenomegalic effect of Salmonella typhi and Shigella flexeneri lysates intranasal vaccination. This splenomegalic effect of Shigella flexeneri lysate was associated with a significant increase of thymus weight at $\mathrm{P}<$ 0.01 , similar thymus response was detected on the use of Staph. aureus lysate intranasal vaccination.

Table (5) and Fig. (5) showed that the different bacterial lysates caused a significant increase in the serum, nasal bed harvest and bronchial lavage Ig $\mathrm{G}$ levels. This increase was non- significant in the serum of the animals vaccinated with Pseudomonas aeroginosa lysate, while those vaccinated with Esch. coli lysate, showed a non- significant drop in the level of seum Ig G.

\section{Histopathological analysis :}

The liver of mice which were vaccinated intranasally with Esch. coli and Ps. aerog. lysate showed activation of Kupffer cells (Figs. 1- 3\&4). That activation of Kupffer cells was associated with mononuclear cellular infiltration in the periportal areas in the animals vaccinated with Shig. flexeneri lysate, Staph. aureus lysate and mixed bacterial lysates (Fig. 16,7\&8). Fig. 1-7 showed lymphocytic infiltration associated with mild degenerative changes in the portal area and ruptured endothelial lining of hepatic-portal vein. Those vaccinated with Salm. typhi lysate revealed congestion of central veins and portal blood vessels, inflammatory lymphocytic infiltration and some cells showed hepatocellular degeneration (Fig. 1-5).

The spleen of mice treated intranasally with Ps. aerog. lysate and Staph aureus lysat showed congested sinusoidal spaces filled with erythrocytes and early signs of inflammation with mononuclear and polymorphonuclear leucocytes, stagnation of blood within splenic vessels that infiltrated the red pulp could be detected (Fig. 2- 4\&7). Bacterial lysates caused a considerable increase in the white pulp, specially the outer part of the periarterial lymphocyte sheath (PALS), where abundant lymphoid cells appeared. The red pulp contained aggrega-tions of large nuclei varying considerably in size (Fig. 2- 4,6 $\& 8)$. The spleen of mice that received Shig. flexeneri lysate showed heavy lymph-ocytic infiltration of mature lymphocytes, plasma cells and macrophages in red pulp (Fig. 26). The spleen of mice treated with Salm. typhi lysate showed degenerative changes. There was a reduction in the overall cellularity of follicles and number of mature lymphocytes. Megakaryocytes were readily lost and myelopoiesis appeared virtually reduced (Fig. 2- 5).

The thymus obtained from animals vaccinated with Esch. coli lysate showed degenerated cells in cortex and medulla of the thymus gland and reduced Hassal's corpuscles (Fig. 3-3), other bacterial lysates caused heavy lymphocytic infiltration (Fig. $3-4,5,6,7 \& 8)$. The thymus sections obtained from mice vaccinated intranasally with $P s$. aerog. lysate showed some cortical and medulla cells that appeared faintly stained, also corticomedullary differentiation was indistinct (Fig. 3-4).The thymus gland section obtained from animals received Shigella flexeneri lysate showed some vaculated cells in medulla and cortex, also bizarre cells or their debris could be detected (Fig. 3-6).

Lung tissues obtained from bacterial lysates intranasally vaccinated animals showed increased lymphocytic and cellular infiltrations. This infiltration was markedly heavy around the wall of the bronchi in the animals treated with Ps. aerog. lysate (Fig. 4-4). Lung sections obtained from animals vaccinated with Salm. typhi lysate intranasally showed mild fluid accumulation inside the alveoli and the small bronchioles and thickened alveolar wall associated with fibrosis (Fig. 4-5). Shig. flexeneri lysate intranasal vaccination caused degenerative changes in the lung tissue and highly thickened alveolar and bronchiolar walls (Fig. 4-6). 
Table (1): peripheral blood total and differential leucocytic counts in bacterial lysates intranasal daily vaccinated animals (7- days).

\begin{tabular}{|l|c|c|c|c|c|}
\hline \multicolumn{1}{|c|}{ ANIMAL GROUP } & $\begin{array}{c}\text { TOTAL } \\
\text { LEUCOCYTIC } \\
\text { COUNT / CMM }\end{array}$ & $\begin{array}{c}\text { EOSIONPHILS } \\
\%\end{array}$ & $\begin{array}{c}\text { NEUTROPHILS } \\
\%\end{array}$ & $\begin{array}{c}\text { LYMPHOCYTES } \\
\%\end{array}$ & $\begin{array}{c}\text { MONOCYTES } \\
\%\end{array}$ \\
\hline NORMAL CONTROL & $3900 \pm 1791$ & $1.88 \pm 2.01$ & $42.4 \pm 3.1$ & $54 \pm 3.0$ & $1.99 \pm 0.86$ \\
\hline PLACEBO & $4135 \pm 1233$ & $1.67 \pm 1.94$ & $41.3 \pm 2.7$ & $53.8 \pm 4.7$ & $1.96 \pm 0.21$ \\
\hline ESCH.COLI ILYSATE & $4471 \pm 1655$ & $1.0 \pm 0.92$ & $53.0 \pm 4.1^{* * *, \infty}$ & $45.1 \pm 3.6^{* \circ}$ & $1.5 \pm 0.76$ \\
\hline S. TYPHI LYSATE & $4017 \pm 1749$ & $1.67 \pm 0.34$ & $40.1 \pm 2.9$ & $54.7 \pm 0.9$ & $2.83 \pm 0.18$ \\
\hline $\begin{array}{l}\text { SHIGELLA FLEXENERI } \\
\text { LYSATE }\end{array}$ & $5000 \pm 1369$ & $1.17 \pm 1.60$ & $44.7 \pm 3.3$ & $51.3 \pm 2.9$ & $2.67 \pm 0.83$ \\
\hline $\begin{array}{l}\text { PSEUDO. AEROGINOSA } \\
\text { LYSATE }\end{array}$ & $4688 \pm 2464$ & $1.54 \pm 0.76$ & $39.6 \pm 3.8$ & $56.5 \pm 4.4$ & $2.13 \pm 0.34$ \\
\hline STAPH. AUREUS LYSATE & $5100 \pm 1873$ & $0.123 \pm 0.34$ & $38.9 \pm 4.9$ & $59.2 \pm 3.8$ & $2.25 \pm 0.97$ \\
\hline $\begin{array}{l}\text { MIXED BACTERIAL } \\
\text { LYSATES }\end{array}$ & $7367 \pm 721^{* * *, \infty}$ & $1.5 \pm 1.38$ & $48.5 \pm 4.6^{*}{ }^{*}$, & $48 \pm 4.4$ & $2.25 \pm 2.84$ \\
\hline
\end{tabular}

$*, * *, * * *$ significant at $\mathrm{P}<0.05,0.01$ and 0.001 , respectively, when compared with control group.

$\circ,{ }^{\circ},{ }^{\text {oo }}$ Significant $a^{\circ}{ }^{\circ} \mathrm{P}<0.05,0.01$ and 0.001 , respectively, when compared with placebo group.

Table (2): Peritoneal fluid total and differential leukocytic counts in bacterial lysatesintranasal daily vaccinated animals (7- days).

\begin{tabular}{|c|c|c|c|c|c|}
\hline ANIMAL GROUP & $\begin{array}{c}\text { TOTAL } \\
\text { LEUCOCYTIC } \\
\text { COUNT / CMM } \\
\end{array}$ & $\begin{array}{c}\text { EOSIONPHILS } \\
\%\end{array}$ & $\begin{array}{c}\text { NEUTROPHILS } \\
\%\end{array}$ & $\begin{array}{c}\text { LYMPHOCYTES } \\
\%\end{array}$ & $\begin{array}{c}\text { MONOCYTES } \\
\%\end{array}$ \\
\hline NORMAL CONTROL & $2800 \pm 1563$ & $0.75 \pm 0.89$ & $48.4 \pm 3.38$ & $49 \pm 1.77$ & $2 \pm 1.17$ \\
\hline Placebo & $2994 \pm 945$ & $0.71 \pm 0.67$ & $49.3 \pm 2.71$ & $48.2 \pm 2.54$ & $1.75 \pm 1.06$ \\
\hline ESCH.COLI LYSATE & $2900 \pm 2379$ & $0.5 \pm 0.76$ & $52 \pm 8.52$ & $58.6 \pm 3.78^{* \circ}$, & $1 \pm 0.76$ \\
\hline S. TYPHI LYSATE & $2133 \pm 920$ & $0.17 \pm 0.38$ & $36.5 \pm 2.17 * * *$ & $62 \pm 2.83 * * *{ }^{\infty \infty}$ & $1.33 \pm 0.82$ \\
\hline SHIGELLA FLEXENERI LYSATE & $1583 \pm 655$ & $0.19 \pm 0.68$ & $41 \pm 1.79 * *$ & $58.5 \pm 1.52 * * *$ & $0.17 \pm 0.41$ \\
\hline $\begin{array}{l}\text { PSEUDO. AEROGINOSA } \\
\text { LYSATE }\end{array}$ & $2216 \pm 1839$ & $1 \pm 0.93$ & $35.5 \pm 5.71 * *$ & $62.3 \pm 5.42 * * *$ & $1.5 \pm 0.96$ \\
\hline STAPH. AUREUS LYSATE & $3040 \pm 1362$ & $0.17 \pm 0.28$ & $42.8 \pm 9.25^{\circ}$ & $55 \pm 7.63$ & $0.13 \pm 0.53$ \\
\hline MIXED BACTERIAL LYSATES & $2790 \pm 1389$ & $0.24 \pm 0.28$ & $39.2 \pm 6.72 *{ }^{\infty}$ & $66.9 \pm 7.21 * * *^{\infty}$ & $1 \pm 0.93$ \\
\hline
\end{tabular}

significant at $\mathrm{P}<0.05,0.01$ and 0.001 , respectively, when compared with control group.
o, oo, oo 
Table (3): Peripheral blood, peritoneal fluid and bone marrow lymphocytic percentage in bacterial lysates-intranasal daily vaccinated animals (7- days).

\begin{tabular}{|c|c|c|c|}
\hline ANIMAL GROUP & $\begin{array}{l}\text { PERIPHERAL BLOOD } \\
\text { LYMPHOCYTES \% }\end{array}$ & $\begin{array}{l}\text { PERITONEAL FLUID } \\
\text { LYMPHOCYTES \% }\end{array}$ & $\begin{array}{c}\text { BONE MARROW LYMPHOCYTES } \\
\% \\
\end{array}$ \\
\hline NORMAL CONTROL & $54 \pm 3.0$ & $49 \pm 1.77$ & $49.9 \pm 5.11$ \\
\hline Placebo & $53.8 \pm 4.7$ & $48.2 \pm 2.54$ & $48.2 \pm 5.63$ \\
\hline ESCH, COLI LYSATE & $45.1 \pm 3.6^{*}$, & $58.6 \pm 3.78 *$, & $48.1 \pm 4.29$ \\
\hline S. TYPHI LYSATE & $54.7 \pm 0.9$ & $62 \pm 2.83 * * *$, oо & $20.3 \pm 3.67 * * *$, , \\
\hline SHIGELLA FLEXENERI LYSATE & $51.3 \pm 2.9$ & $58.5 \pm 1.52 * * *$, & $40.5 \pm 3.83$ \\
\hline PSEUdo. AEROGINOSA LYSATE & $56.5 \pm 4.4$ & $62.3 \pm 5.42 * * *$, , & $50.1 \pm 3.43$ \\
\hline STAPH. AUREUS LYSATE & $59.2 \pm 3.8$ & $55 \pm 7.63$ & $38.5 \pm 4.14 *$ \\
\hline MIXED BACTERIAL LYSATES & $48 \pm 4.4$ & $66.9 \pm 7.21 * *, o$ & $64.1 \pm 8.45^{*}, \circ$ \\
\hline
\end{tabular}

$*, * *, * * * \quad$ significant at $\mathrm{P}<0.05,0.01$ and 0.001 , respectively, when compared with control group.

$\stackrel{\circ}{\circ}{ }^{\infty},{ }^{\infty}$ significant at $\mathrm{P}<0.05,0.01$ and 0.001 , respectively, when compared with placebo group.

Table (4): Total body weight (T), liver (L), spleen (S) and thymus (Th) weight and $\mathrm{L}+\mathrm{S}+$ $\mathrm{Th} / \mathrm{T}$ ratio in bacterial lysate-intranasal daily vaccinated animals (7- days).

\begin{tabular}{|l|c|c|c|c|c|}
\hline ANIMAL GROUP & $\begin{array}{c}\text { TOTAL } \\
\text { BODY } \\
\text { WEIGHT (T) } \\
\text { IN GMS }\end{array}$ & $\begin{array}{c}\text { LIVER (L) } \\
\text { WEIGHT IN } \\
\text { GMS }\end{array}$ & $\begin{array}{c}\text { SPLEEN (S) } \\
\text { WEIGHT IN GMS }\end{array}$ & $\begin{array}{c}\text { THYMUS (TH) } \\
\text { WEIGHT IN GMS }\end{array}$ & L+S+TH/T RATIO \\
\hline $\begin{array}{l}\text { NORMAL } \\
\text { CONTROL }\end{array}$ & $24.2 \pm 3.49$ & $1.11 \pm 0.25$ & $0.123 \pm 0.03$ & $0.041 \pm 0.006$ & $0.053 \pm 0.007$ \\
\hline PLACEBO & $24.9 \pm 4.26$ & $1.18 \pm 0.28$ & $0.125 \pm 0.04$ & $0.04 \pm 0.002$ & $0.055 \pm 0.006$ \\
\hline $\begin{array}{l}\text { ESCH.COLI } \\
\text { LYSATE }\end{array}$ & $27.1 \pm 4.99$ & $1.35 \pm 0.36$ & $1.162 \pm 0.04$ & $0.034 \pm 0.004$ & $0.055 \pm 0.007$ \\
\hline S. TYPHI LYSATE & $25.9 \pm 0.64$ & $1.12 \pm 0.22$ & $0.246 \pm 0.04 * * *, 000$ & $0.043 \pm 0.002$ & $0.054 \pm 0.001$ \\
\hline $\begin{array}{l}\text { SHIGELLA } \\
\text { FLEXENERI } \\
\text { LYSATE }\end{array}$ & $25.7 \pm 1.81$ & $1.19 \pm 0.18$ & $0.205 \pm 0.02 * * *, 000$ & $0.052 \pm 0.003 * *, \infty$ & $0.056 \pm 0.004$ \\
\hline $\begin{array}{l}\text { PSEUDO. } \\
\text { AEROGINOSA } \\
\text { LYSATE }\end{array}$ & $24.7 \pm 2.16$ & $1.17 \pm 0.24$ & $0.150 \pm 0.05$ & $0.046 \pm 0.006$ & $0.055 \pm 0.01$ \\
\hline $\begin{array}{l}\text { STAPH. AUREUS } \\
\text { LYSATE }\end{array}$ & $25.8 \pm 3.13$ & $1.13 \pm 0.26$ & $0.133 \pm 0.05$ & $0.049 \pm 0.001 *$, & $0.051 \pm 0.008$ \\
\hline $\begin{array}{l}\text { MIXED } \\
\text { BACTERIAL } \\
\text { LYSATES }\end{array}$ & $24.4 \pm 2.26$ & $1.10 \pm 0.08$ & $0.125 \pm 0.02$ & $0.047 \pm 0.002$ & $0.050 \pm 0.002$ \\
\hline
\end{tabular}

$*, * *, * * *$ significant at $\mathrm{P}<0.05,0.01$ and 0.001 , respectively, when compared with control group.

${ }^{\circ},{ }^{\circ o},{ }^{\text {ooo }}$ significant at $\mathrm{P}<0.05,0.01$ and 0.001 , respectively, when compared with placebo group. 
Table (5): Immunoglobulin G (IgG) levels using plate diffusion method in the serum, bronchial lavage and nasal harvest in the different bacterial lysates-intranasal treated animals (daily vaccinated for seven days).

\begin{tabular}{|c|c|c|c|}
\hline \multirow[t]{2}{*}{ ANIMAL GROUP } & \multicolumn{3}{|c|}{ IGG MG/L } \\
\hline & SERUM & BRONCHIAL LAVAGE & NSAL HARVEST \\
\hline NORMAL CONTROL & $27.2 \pm 4.6$ & $16.2 \pm 3.9$ & $17.3 \pm 2.2$ \\
\hline PLACEBO & $27.3 \pm 4.4$ & $16.5 \pm 3.1$ & $18.4 \pm 1.9$ \\
\hline ESCH.COLI LYSATE & $19.9 \pm 10.4$ & $36.8 \pm 4.9 * * *, \infty$ & $33.9 \pm 1.9 * * *$ \\
\hline S. TYPHI LYSATE & $35.6 \pm 3.5^{*},{ }^{\circ}$ & $40.9 \pm 4.2 * * *$, , & $23.2 \pm 3.1 *, o$ \\
\hline SHIGELLA FLEXENERI LYSATE & $39.7 \pm 5.1 *, \circ$ & $34.2 \pm 2.9 * * *,{ }^{\circ o 0}$ & $37.3 \pm 7.4 * * *,{ }^{\text {о о }}$ \\
\hline PSEUDO. AEROGINOSA LYSATE & $36.3 \pm 9.6$ & $39.1 \pm 3.8 * * *$, oo & $34.1 \pm 1.6 * * *$, \\
\hline STAPH. AUREUS LYSATE & $36.8 \pm 3.8 *$, & $30 \pm 6.4 * *, \circ$ & $37 \pm 3.6 * * *,{ }^{* 00}$ \\
\hline MIXED BACTERIAL LYSATES & $44.4 \pm 3.2 * * *$, , oo & $36.3 \pm 3.7 * * *,{ }^{\circ \infty}$ & $25.4 \pm 2.7 * *$, o \\
\hline
\end{tabular}

$*, * *, * * *$ significant at $\mathrm{P}<0.05,0.01$ and 0.001 , respectively, when compared with control group.

${ }^{\circ},{ }^{o o},{ }^{\text {ooo }}$ significant at $\mathrm{P}<0.05,0.01$ and 0.001 , respectively, when compared with placebo group. 

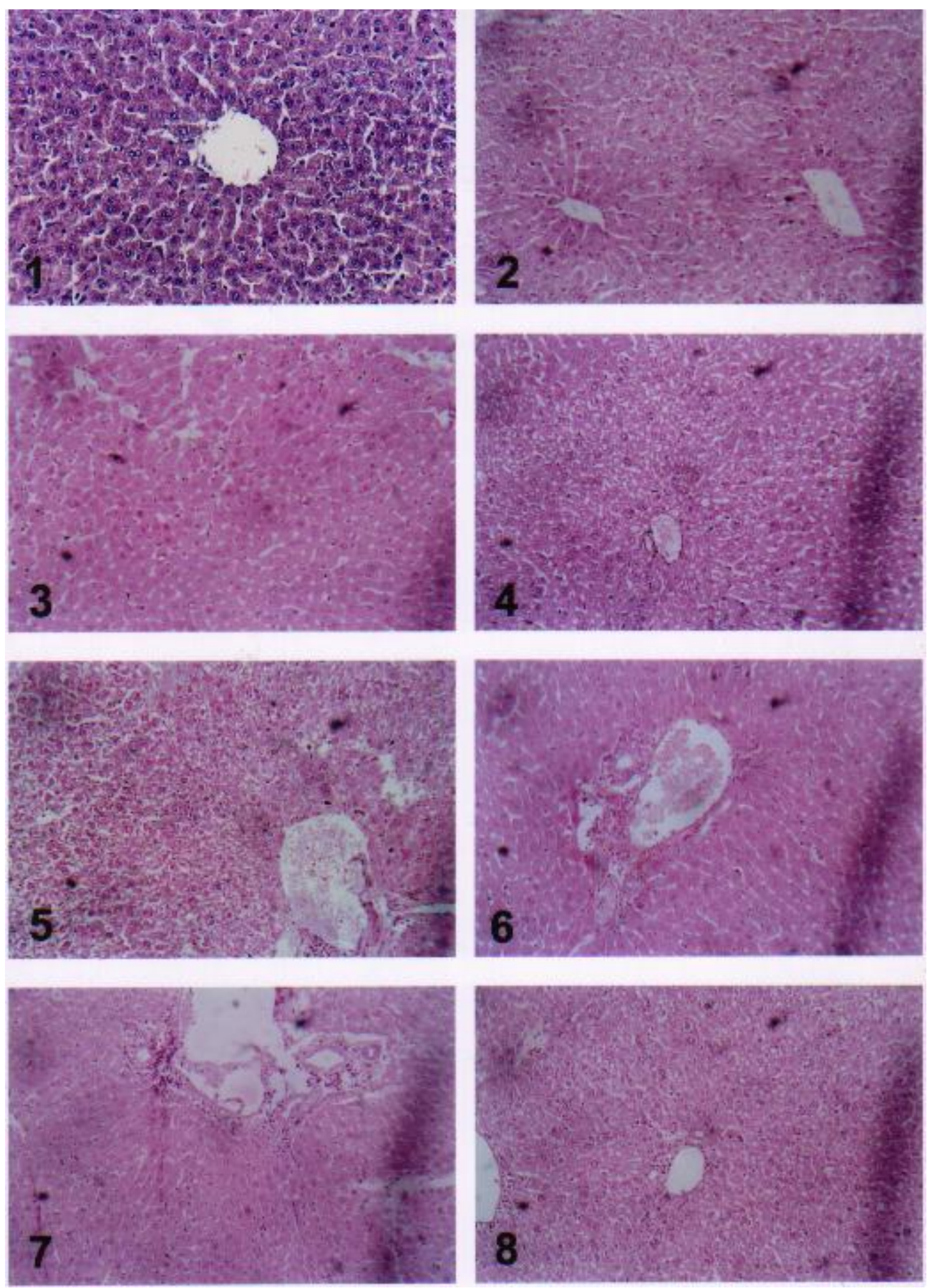

Fig. (1): Liver sections showing: 1- Normal control 2- Placebo treated 3- Esch coli lysate 4- Ps aeroginosa lysate 5- Salm typhi lysate 6- Shig flexeneri lysate 7- Staph aureus lysate 8- Mixed bacterial lysates (H\&E). X200 

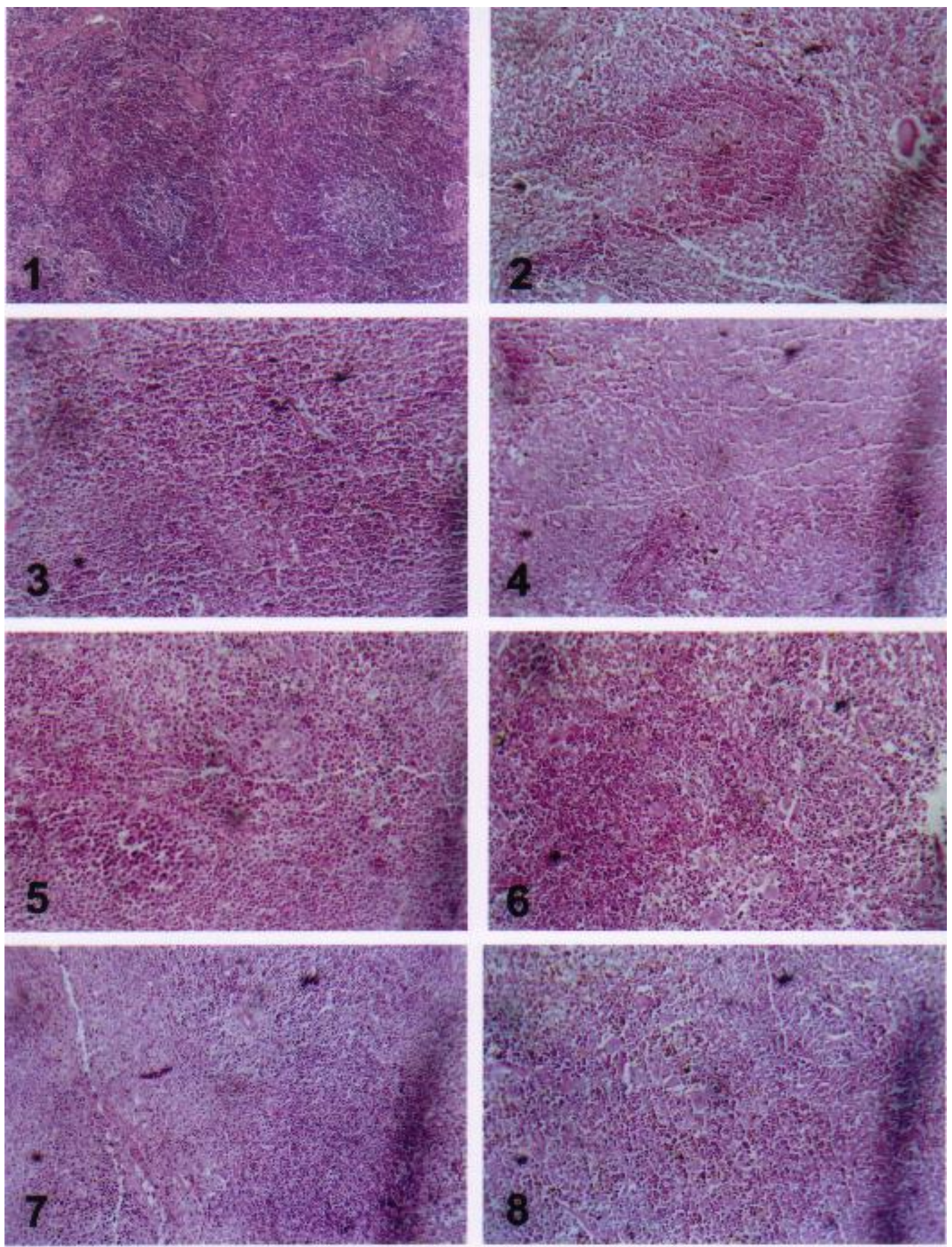

Fig. (2): Spleen sections showing: 1- Normal control 2- Placebo treated 3- Esch coli lysate 4- Ps aeroginosa lysate 5- Salm typhi lysate 6- Shig flexeneri lysate 7- Staph aureus lysate 8- Mixed bacterial lysates (H\&E). X200 

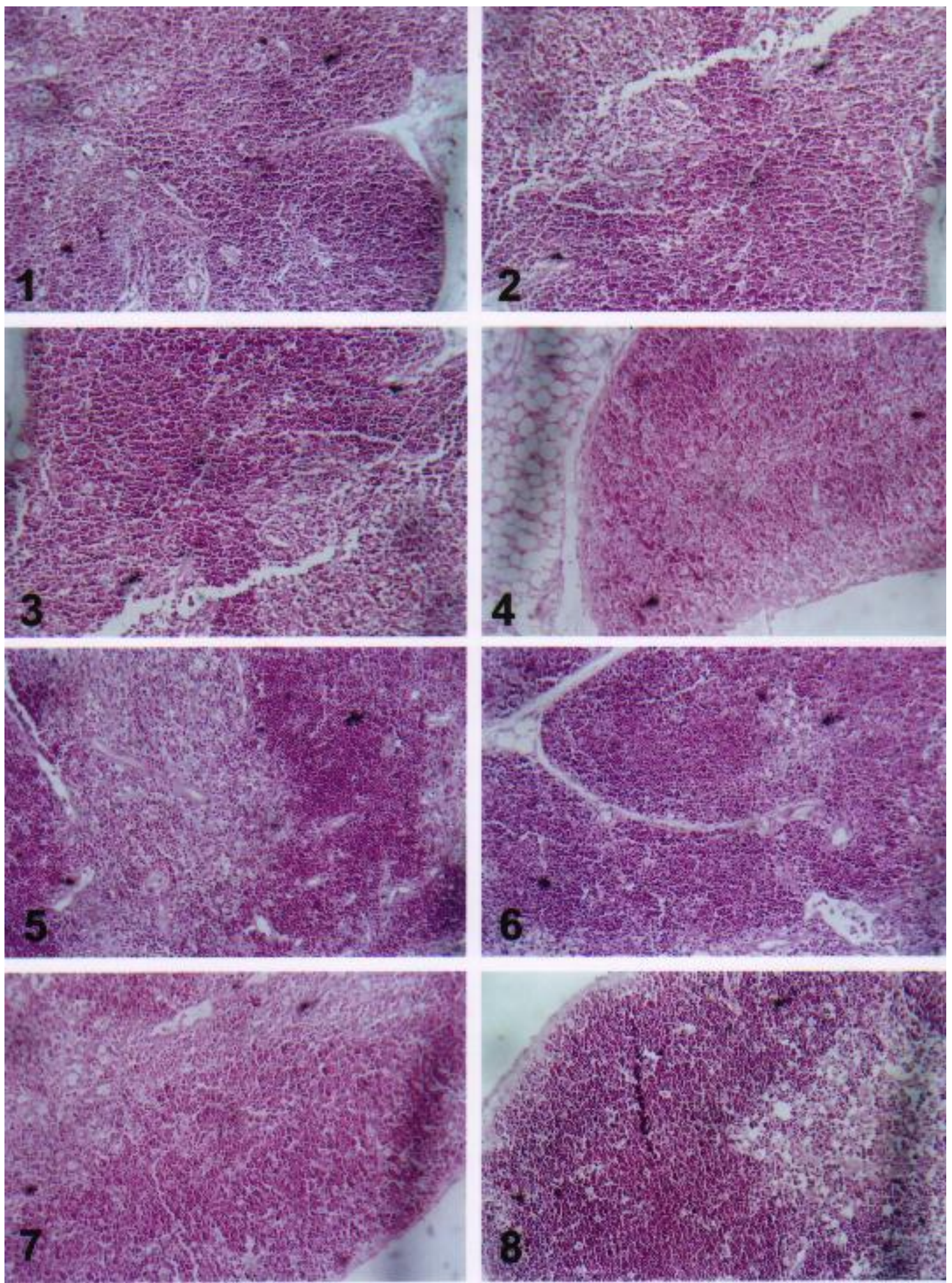

Fig. (3): Thymus sections showing: 1- Normal control 2- Placebo treated 3- Esch coli lysate 4- Ps aeroginosa lysate 5- Salm typhi lysate 6-Shig flexeneri lysate 7-Staph aureus lysate 8- Mixed bacterial lysates (H\&E). X200 

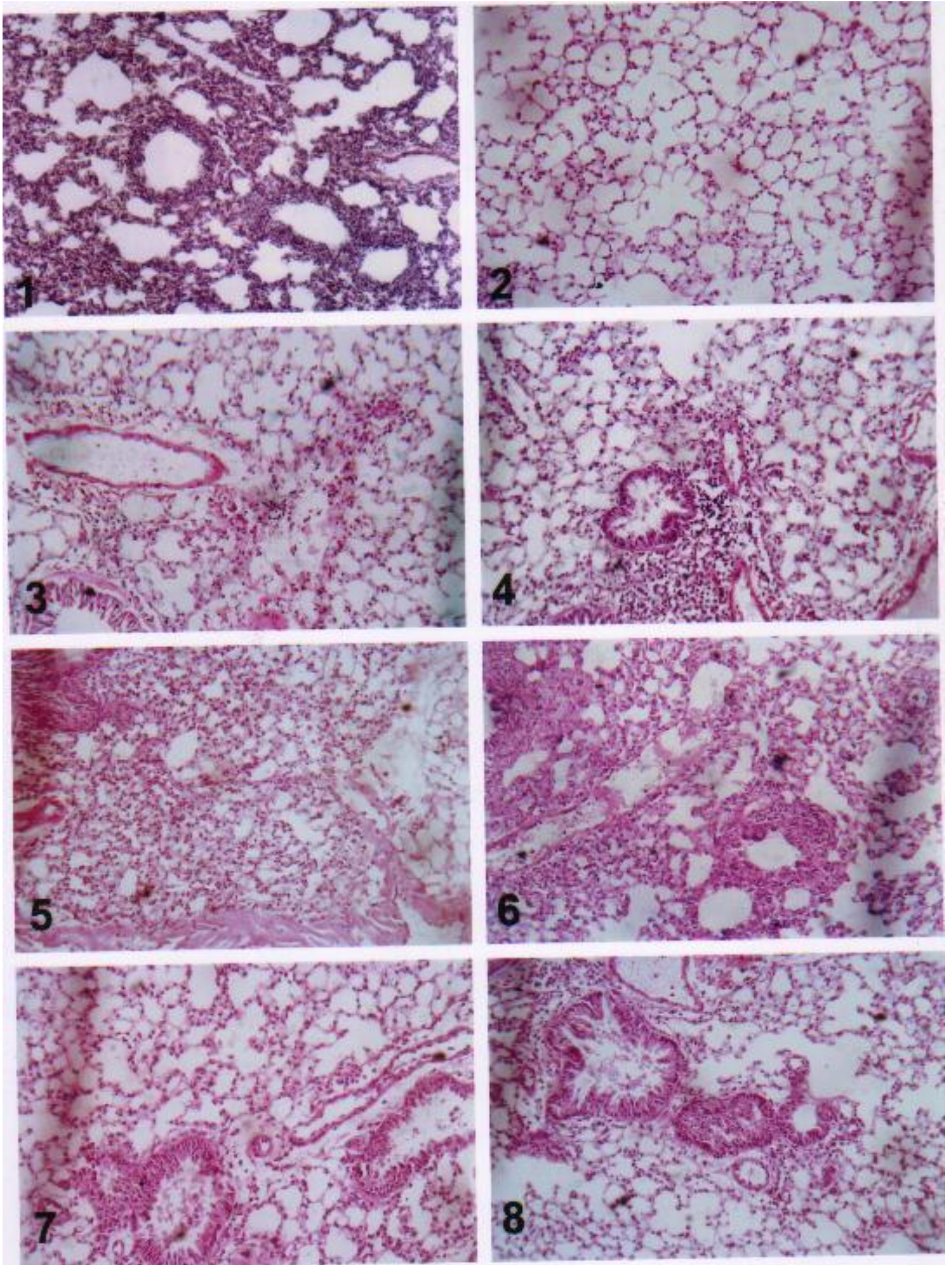

Fig. (4): Lung sections showing: 1- Normal control 2- Placebo treated 3- Esch coli lysate 4- Ps aeroginosa lysate 5- Salm typhi lysate 6-Shig flexeneri lysate 7-Staph aureus lysate 8- Mixed bacterial lysates (H\&E). X200 


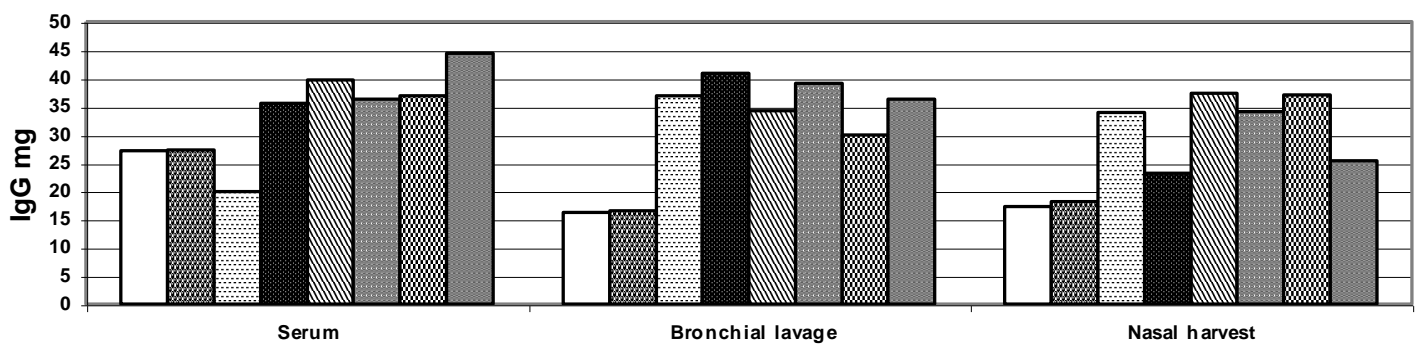

Fig. (5): Immunoglobulin G(IgG) levels using plate diffusion method in the serum, bronchial lavage and nasal bed harvest in the different bacterial lysatesintranasal treated animalsdaily $v$ accinated fort days (according to table5).

\section{Discussion}

Bacterial vaccines are those composed of killed bacterial products. This study has approached the immunoprophylaxis effect of bacterial vaccines using the whole cell bacterial lysates. Goncharova et al. (2002), mentioned that nasal mucosa in the olfactory region is likely to be a promising target for mucosal immunization. The use of oral and intranasal bacterial vaccines stimulate the local and distant effector site such as the intestinal mucosa and the respiratory tract, the microorganism can elicit an enhanced Ig A response according to the concept of a common mucosaassociated immune system (Ruedl et al., 1994). Intranasal immunization delivers the antigen directly to the site of uptake (Kuper et al., 1992). The stimulation of cells from the spleen and mesenteric lymph nodes after nasal immunization points to the existence of a common mucosal immune system (Bonenfant et al., 2001). This may explain the significant increase in peritoneal fluid lymphocytic count recorded in this study that was associated with a significant increase of spleen and thymus weights. On the use of mixed bacterial lysates, these changes were accompanied by significant increase of bone marrow lymphocytic percentage. Kiyono et al. (1992) and Porgador et al. (1998) found that cells stimulated in the nasal associated lymphoid tissue (NALT) by the antigen presented by antigen-presenting cells can leave this site for mucosal effector sites. Nasal immunization triggers pulmonary immunity. Antigen administered by the nasal route can reach the trachea area or dendritic cells loaded with the antigen, may have migrated from the NALT to the pulmonary lymph nodes, where they can initiate an immune response (Trolle et al., 1999). Intranasal immunization triggers both mucosal and systemic $\mathrm{T}$ and $\mathrm{B}$-cell responses ( $\mathrm{Wu}$ and Russell, 1997 and $\mathrm{Wu}$ et al., 1997). Edinboro et al., (2004) showed that intranasal vaccines could prevent tracheobronchitis in dogs. These reports explain the highly significant increase in the level of Ig $\mathrm{G}$ in bronchial lavage and nasal bed harvest in the different intranasal bacterial lysates vaccinated mice, also the significant increase in the serum Ig G. These findings were also supported by Kuenen et al., 1994 who mentioned that the protective effect of bacterial lysates is accoimpanied by priming for specific Ig $G$ responsiveness. Teloni et al. (2004) mentioned that bacterial proteins and oligodeoxynucle-otides 
applied intranasally rised antibody classes and subclasses.

This study dealt with the immune changes in response to intranasal vaccination with Esch. coli lysate, Pseudomonas aeroginosa lysate, Salmonella typhi lysate, Shigella flexeneri lysate, Staph. aureus lysate and mixed bacterial lysates. Ryan et al. (1999) mentioned that Esch. coli heat labile toxin act as effective mucosal adjuvant for nasal delivery of acellular pertussis vaccine. Bennet-Guerrero et al., (2000) found that active immunization of mice with complete core LPS of Esch. coli, Pseudomonas aeroginosa and Bacteroids fragilis mixed together to form a cocktail, provided protection against a lethal challenge with Esch. coli. The vaccine was non toxic, non pyrogenic and immunogenic against a wide variety of pathogens found clinically. The inactivated bacterial lysates used in this study, in the given dose, proved to be non- toxic and immunostimulant. Harrison et al. (1997) used Salmonella typhimurium vaccine in the murine typhoid model. On the other hand, this strain was used by Corthesy-Theulas et al., (1998) for protecting mice from Helicobacter pylori infection by nasal immunization. Furlong and David, (1996) mentioned that shigella liposaccharides complexes can be used as an effective immunogen. These proteosomes preparations induce an effective mucosal response when delivered either orally or intranasally and cause protection against shigella infections ( Orr et al., 1993). O' Brien et al. (2000) studied the protective effect of Staph aureus lysate. Both Rutishauser et al., (1998) and Ruah et al. (2001) studied the immunoprotective effect of mixed bacterial lysates against recurrent respiratory tract infections.

In this study, histological changes of liver, thymus, spleen, lung and bronchi showed morphological differences depending on the type of vaccine used. Preparations were characterized by stimulating effect on reticuloendothelial system, which was much pronounced after giving mixed bacterial lysates. Haschek and Rouseaux, (1998) mentioned that the morphological response can be considered as involution of lymphoid organs were the thymus being very susceptible to toxic injury and also hyperplasia occurred. Bacterial endotoxins can induce mild hepatic inflammation and varying degrees of hepatcellular cholestasis. The later effect is attributed to the effects of proinflammatory cytokines, released by Kupffer cells and endothelial cells in response to circulating endotoxin (Cotran et al., 1999). Trauner et al. (1999) illustrated that intrahepatic cholestasis ( inflammationinduced cholestasis) is induced by inflammatory cytokines in response to various infectious stimuli causing liver oedema, ballooning and cellular infiltration. These cytokine effects are reversible and bile secreting function is restored upon disappearance of the inflammatory injury. In this study, liver inflammatory response to bacterial lysates was clear when Salmonella typhi lysate, Pseudomonas aeroginosa lysate, Shigella flexeneri lysate and Staph. aureus lysate were used. Sakiri et al., (1998) stated that shigella toxins caused tissue damage and vascular lesions in which endothelial cells were swollen and detached from underlying basement membranes. They showed also that these vascular changes occur in the presence of proinflammatory cytokines tumor necrosis factoralpha (TNF- $\alpha$ ) or interleukin -1 beta (IL- 1 $\beta)$. Liver sections in this study illustrated liver cell damage changes and vascular lesions and congestion in response to Shigella flexeneri lysate. Polotskii et al., (1981) said that shigella lysates caused an increased number of cellular lymphocytic infiltration. This observation was recorded in this study in liver sections, spleen, thymus and lung tissue. The spleen of mice that received Shig. flexeneri lysate sections showed red pulp contained aggregations of large nuclei varying considerably in size , heavy lymphocytic infiltration of mature lymphocytes, plasma cells and macrophages in red pulp (Fig. 2-6). The thymus gland section obtained from animals received Shigella flexeneri lysate showed some vaculated cells in medulla and cortex, also bizarre cells or their debris could be detected.

Respiratory tract histopathological study revealed increased cellular infiltration 
of polymorphonuclear leucocytes (PMNs) and monocytes in response to bacterial lysates, these infiltrates were also detected in bronchoalveolar fluid. Wagner et al, (1999) mentioned that bronchoalveolar lavage (BALF)- PMN accumulation in response to intratracheal treatment with LPS was $100 \%$. In contrast, intravenous endotoxemia inhibited pulmonary PMN migration. Fan et al. (1998) showed that in a rodent model, animals exposed to antecedent shock exhibited augmented lung inflammation in response to LPS resuscitated shock where enhanced lung neutrophil sequestration and transpulmonary albumin flux in response to intratracheal LPS. They mentioned that primed alveolar macrophages play a major role in enhanced lung leucosequestration and transpulmonary flux in response to LPS following resuscitated shock. Both Mmin et al (1979) and van Daal et al. (1992) showed that polyvalent bacterial lysates could protect against respiratory diseases. They showed that immunization with bacterial lysates reduced the intrapulmonary inflammatory reaction to infection, that was assessed by measurement of PMN elastase in BALF.

This study concludes that immunization through the nasal route is an adequate and efficient method of vaccine delivery, this route also offered effective priming . Bacterial lysates play a role as immunostimulant- immunomodulator vaccines. Further studies are needed to establish safe limits of endotoxins in vaccines in different animal models ( Mader et al., 1997 ). Also, more studies should be carried out to assess lung injury by priming for an exagg-erated response to a second stimulus, the so-called " two-hit " hypothesis (Fan et al., 1998).

\section{References}

1. Ambrosino, D.M. (1996): Bacterial vaccines. In: Therapeutic Immunology . K.F. Austen; S.J. Burakoff and F.S. Rosen (eds.) pp. 419- 427. Blackwell Science.

2. Bennet-Guerrero, E; McIntosh T.J.; Barclay, G.R.; Snyder, D.S.,Gibbs, R.; Mythen, M.G and Poxton, I.R. (2000): Preparation and preclinical evaluation of a novel liposomal complete-core lipopoly sacchaaride vaccine. Infecct. Immun. 68(11): 62026208.

3. Bey, R.; Simonson, R. and Garcon, N.(1997): Formulation of vaccines. In: Development and Formation of Veterinary Dosage Forms. G.E. Hardee and J.D. Baggot (eds.). pp. 283-303. Marcel Dekker Inc. New York. Basel. Hong Kong.

4. Bonenfant, C.; Dimier-Boisson, I.; Velge-Roussal, F.; Buzoni Gatel D.D.; Guidice, G.; Rappuoli,R. and Bout, D. (2001): Intranasal immunization with SAG 1 and nontoxic mutant heat labile enteroto-xins protects mice against Toxoplasma gondii. Infect. Immun. 69 (3): 1605-1612.

5. Ciebiada, I.; Bloch, P.; Kulig,A. and Denys, A. ( 1989): Studies of the effects of BCG and Corynbacterium parvum vaccines in experimental infection of mice with influenza virus. Foot pad test, splenic indicator and histologic changes in the thymus gland, spleen and lysmph nodes. Med. DOSW Microbiol. 41(2): 92-99. (Polish, with English abstract).

6. -Corthesy-Theulaz, I.E., Hopkin S.; Bachmann, D.;Saldinger, P.F.; Porta, N.; Haas, R.; ZhengXin, Y; Meyer, T.; Bouzourene, H.; Blum, A.L. and Kraehen bulh, J.P. (1998):Mice are protected from Helicobacter pylori infection by nasal immunization with attenuated Salmonella typhimurium pho Pc expressing urease $\mathrm{A}$ and $\mathrm{B}$ subunits. Infect. Immun. 66: 581- 586.

7. Cotran, R.S.; Kumar, V. and Collins, T. (1999): Infectious diseases. In: Pathologic Basis Of Disease. (eds.). Pp:332- 402. W.B. Saunders Company. A Division of Harcourt Brace\& Company. Philadelphia, London, Toronto, Montreal, Sydney, Tokyo.

8. Di-Tommaso, A.; Saletti, G.; Pizza, M.; Rappuoli, R.; Dougan, G.; Abrignani, S.; Douce, G. and De magistris, M. T. (1996) : 
Induction of antigen specific antibodies in vaginal secretions by using a nontoxic mu-tant of heat labile enterotoxin as a mucosal adjuvant. Infect. Immun. 64: 974979.

9. Edinboro, C.H.; Ward, M.P. and Glickman, L.T. (2004): A plcebocontrolled trial of two intranasal vaccines to prevent tracheobronchitis (kennel cough) in dogs entering a human shelter. Prev. Vet. Med. 62(2): 89- 99.

10. Fahey, J.L. and Mc Kelvey, E.M. (1965): Quantitative determination of serum; imm-uneoglobulins in antibody-agar plates. J. Immunol. 94:84-90.

11. Fan, J.; Marshall, J. C.; Jimeney, M.; Shek, P.N.; Zagorski, J. and Rotstein, O.D. 1998: Hemorrhagic shoch primes for increased expression of cytokine-induced neutrophil chemoattractant in the lung: role in pulmonary inflammation following lipopolysaccharide. J.Immunol. 161 (1): 440-447.

12. Furlong, S.T. and David, J.R. (1996): Adjuvant therapy. In: Therapeutic Immun-ology. K. FrankAusten; Steven J. Burakoff; Fred, S. Rosen and Ferry B. Strom (eds.) pp. 605-614. Blackwell Science.

13. Gawlik, R. and Danek, K. (1999): Immunomodulation with bacterial vaccines in chronic respiratory diseases .Wiad. Lek. 52 (9-10) : 470-475. [In Polish with English abstract].

14. Goldstein, A. (1964): In: Biostatestics, and introductory text. Macmillan, Co. New York, PP. 101-106.

15. Goncharova, E.P.; Ryzhikov, A. B.; Bulychov, L.E.; Sizov, A.A.; Lebedev, L.; Poryvaev, V.D.; Karpenko, L.I. and Il'ichev, A.A. (2002): A study of systems for delivering antigens and plasmid DNA intranasal immunization against tick-borne encephalitis virus. Wien. Klin. Woche-nscher. 114(13-14): 630-635 [In Russian with English abstract].

16. Greenbaum, E.; Engelhard, D.; Levy, R.; Schlezinger, M.;
Morag, A. and Zakay- Rones, Z. (2004): Mucosal (S Ig A) and serum (Ig G) immunologic responses in young adults following intranasal adminis-tration of one or two doses of inactivated antiinfluenza vaccine. Vaccine. 22(20): 2566- 2577.

17. Grevers, G.; Palacios, O.A.; Rodriquez, B.; Abel, S. and van Aubel, A. (2000): Treatment of recurrent respiratory tract infections with a polyvalent bacterial lysate: results of an open, prospective multinational study. Adv. Ther. 17 (2):103-116.

18. Harrison, J.A.; Villareal-Ramos, B.; Mastroeni, P.; Demarco de Horma, R. and Hormaeche, C.E. (1997): Correlates of protection induced by live Aro-Salmonella typhimurium vaccines in the murine typho-id model. Immunology. 90 (4): 618-625.

19. Haschek, W.M. and Rousseaux, C. G. (1998): Immune system. In: Fundamentals of Toxicologic Pathology. (eds.). pp. 260-273. Academic Press. San Diego. London. New York. Boston. Sydney. Tokyo. Toronto.

20. Havlasova, J.; Hernychova, L.; Halada, P.; Pellantova, V.; Krejsek, J.; Stulik, J.; Macela, A.; Jugblut, P.R.; Larsson, P. and Forsman, M. (2002): Mapping of immune-oreactive antigens of Francisella tularensis live vaccine strain. Proteomics. 2 (7): 857-867.

21. Hirabayashi, Y.; Kurata, H.; Furato, H.; Nagamine, T.; Aizawa, C.; Tamura, S.; Shimada, K. and Kurata, T. (1990): Comparison of intranasal inoculation of influenza $\mathrm{H}$ A vaccine combined with cholera toxin B subunit with oral or parenteral vaccination. Vaccine 8: 243248.

22. Hugo, W.B. and Russel, A.D. (1993): The manufacture and quality control of immune-ological products. In: Pharmaceutical Microbiology. (eds). Pp. 332-350. Blackwell Scientific Publications. London. Edinburg. Boston. Melbourne. Paris. Berlin. Vienna. 
23. Jakobsen, H.; Schulz, D.; Pizza, M.; Rappuoli, R. and Jonsdottir, I. (1999): Intranasal immunization with pneumococcal polysaccharide conjugate vaccines with non-toxic mutants of Esch. coli heat- labile enterotoxins as adjuvants protects mice against invasive pneumococcal infections. Infect. Immun. 67: 5892-5897.

24. Kim, S.Y.; Doh, H.J.; Ahn, J.S.; Ha, Y. J.; Jang, M.H.; Chung, S.I. and Park, H.J. (1999): Induction of musocal and systemic immune response by oral immunization with H. Pylori lysates encapsulated in poly ( $\mathrm{Di}$ lactide-co-glycolide)

microparticles. Vaccine. 17 (6): 607-616.

25. Kiyono, H.; Bienestock, J.; Mc Ghee, J.R. and Ernst, P.B. (1992): The mucosal immune system: features of inductive and effector sites to consider in mucosal immunization and vaccine development. Reg. Immunol. 4: 5462.

26. Kuenen, J. D.; Van Dijke, E.E.; Hol, C.; Bootsma, H.J.; Verhoef, J.and Van Dijk, H. (1994): Protective effects of orally administered, klebsiella-containing bacterial lysates in mice.

FEMS Immunol. Med. Microbiol. 8 (1).: 69-75.

27. Kuper,C. F.; Koornstra， P. J.; Hameleers,

D.M.;

Biewenga,J.;Spit, B. J.; Duijvestijn, A.M.; van Breda Vriesman, P. J. and Sinia, T. (1992): The role of nasopharyngeal lymphoid tissue. Immunol Today 13: 219- 224.

28. Mader， H.J.; Szostak, M.P.; Hensel, A.; Lubitz and Haslberger, A.G. (1997): Endotoxicity does not limit the use of bacterial ghosts as candidate vaccines. Vaccine. 15 (2); 195-202.

29. Marchetti, M.; Rossi, M. ; Giannelli, V. ; Giuliani, M. M. ; Pizza, M. ; Censini, S. ; Covacci, A. ; Massari, P. ; Pagliaccia, C. ; Manetti, R. ; Telford, J.L. ; Douce, G.; Dougan, G.; Rappuoli, R. and Ghiara, P. (1998): Protection against Helicobacter pylori infection in mice by intragastric vaccination with $H$. pylori antigens is achieved using a non-toxic mutant of Esch. coli heatlabile enterotoxin (LT) as adjuvant. Vaccine. 16: 33-37.

30. Memin, Y.; Fabre, C.; Laribaud, J. and Dry, J. (1979): Study of the preventive action of a polybacterian lysate against some respiratory diseases in a geriatric population. Therapie 34(4): 475-480.

31. O'Brien, C.N.; Guidry, A.J.; Douglass, L.W. and Westhoff, D.C. (2000): Immun-ization with Staphylococcus aureus lysate incorporaints microsphers. J. Dairy Sci. 84(8): 1791-1799.

32. Okamoto, s.; Kawabata, S.; Fujitaka, H.; Uehira,T. Okuno,Y. and Hamada,S. (2004): Vaccination with formalininactiated influenza vaccine protects mice against lethal influenza Streptococcus pyogenes superinfection. Vaccine. 22(21-22): 2887- 2893.

33. Orr, N.; Robin, G. and Cohen, D. (1993): Immunogenicity and efficacy of oral or intranasal Shigella flexneri and shigellasonnei proteosomelipopolysaccharide vacc-ines in animal models. Infect. Immun. 61: 2390-2395.

34.Partidos, C.D.; Salani, B. F.; Pizza, M. and Rappuoli,R.(1999): heat-labile entero-toxin of Escherichia coli and its sitedirected mutant LTK 63 enhance the proliferative and cytotoxic $\mathrm{T}$ cell responses intranasally coimmunized synthetic peptides. Immunol. Lett. 67: 209-216.

35. Polotskii, Iu. E.; Rukhamina, M. L.; Krasnoprohina, L. I.; Seliverstova, V.G. and Kolomiets, O. L. (1981): Study of enteric dysentery vaccines and their efficacy on a rabbit intestinal loop model . II. Changes in the mucosa of rabbit small intestine after oral immunization with live and chemical vaccines. Mikrobiol. Epide-miol. Immunobiol. 1: 89-94 [ Russian with English abstract].

36. Porgador, A.; Staats, H. F.; Itoh, Y. and Kelsall, B.L. (1998): 
Intranasal immune-ization with cytotoxic T-lymphocytes epit-ope peptide and mucosal adjuvant cholera toxin: selective augmentation of peptide presenting dendritic cells in nasal mucosaassociated lymphoid tissue. Infect. Immun. 66: 5876-5881.

37. Raghavan, S.; Hjulstrom, M., Holingren, J. and Svennerholm, A.M. (2002): Prote-ction against experimental Helicobactor pylori infection after immunization with inactivated $\mathrm{H}$. pylori whole-cell vaccines. Infect. Immun. 70 (11): 63836388.

38. Ruah, S.B.; Ruah, C.; Van Aubel, A.; Abel, S. and Elsasser, U.(2001) : Efficacy of a polyvalent bacterial lysate in children with recurrent respiratory tract infections. Adv. Ther. 18 (4): 151-162.

39. Ruedl, C.; Fruhwirth, M; Wick, G. and Wolf H. (1994): Immune respone in the lengs following oral immunization with bacterial lysates of respiratory pathogens. Clin. Diagn. Lab.Immunol. 1(2): 150-154.

40. Rutishauser, M.; Pitzke, P.; Grevers, G.; Van Aubel, A.; Elsasser,U. and Kammereit, A. (1998): Use of a polyvalent bacterial lysate in patients with recurrent respiratory tract infections: results of a prospective, placebo-controlled, randomized, do-uble- blind study. Adv. Ther. 15(6):330 341.

41. Ryan, E. J.; Mc Neela, E. ; Murphy, G. A. ; Stewart, H.; O'Hagan, D.; Pizza, M.; Rappuoli, R. and Mills, K. H. (1999): Mutants of Escherichia coli heat-labile toxin act as effective mucosal adjuvants for nasal delivery of an acellular pertussis vaccine: differential effects of the nontoxic $\mathrm{AB}$ complex and activity on Th1 and Th2 cells. Infect. Immun. 67: 6270-6280.

42. -Sadeq, R.A.; El-Kady, L. and Fahmy, K. (1992): Requirements of Opsonophagocy-tosis of Staphylococci. Egypt. J. Med. Microbiol. 1 (1): 35-38.
43. Sakiri, R.; Ramegowch, B. and Tesh, V. L. (1998): Shiga toxin type 1 activates tumor necrosis factor- alpha gene transcr-iption and nuclear translocation of the transcriptional activator nuclear factor- kappa B and activator protein-1. Blood 92 (2): 558-566.

44. Teloni, R.; Hunnnolstein, C. V., Mariotti, S. ; Donati, S. ; Orefici, G. and Nisini, R. (2004): Antibody classes and subclasses induced by mucosal immunization of mice with Streptococcus pyogenes M6 protein $\& \quad$ oligodeoxynucleotides containing $\mathrm{CpG}$ motifs. Indian J. Med. Res. 119: 126-130.

45. Trauner, M.; Fishert, P. and Stauber, R. E.(1999): Inflammation- induced cholestasis.J.Gastroenterol.Hepatol.14(10): 946- 959.

46. Trolle, S.; Caudron, E.; Leo, E, ; Couvreur, P.; Andremont, A. and Fattal, E. (1999) : In- vivo fate and immune pulm-onary response after nasal administration of microspheres loaded with phosphorocholine- thyroglobulin. Int. J. Pharm. 183: 73- 79.

47. van Daal, G. L.; van't Veen, A.; So, K. L.; Mouton, J. W.; Smit, F.; van Hal, P. T.; Bergmann, K. C. and Lachmann, B. (1992): Oral immunization with polyvalent bacterial lysate and infection with Streptococcus pneumoniae: influence on interferon-gamma and PMN elastase concentrations in murine bronchoalveolar lavage fluid. Int. Arch. Allergy Immunol. 97(2): 173- 177.

48. Wagner, J. G.; Driscoll, K. E. and Roth, R. A. (1999): Inhibition of neutrophil trafficking during endotoxemia is dependent on the stimulus of migration. Am. J. Rrspir. Cell. Mol. Biol. 20(4): 769776.

49. Williamson, E. D.; Eley, S. M.; Stagg, A. J.; Green, M.; Russell, P. and Titball, R. W. (2000): A single dose sub- unit vaccine protects against pneumonic plague. Vaccine. 19(4-5): 566- 571.

50. Wu, H. Y. and Russell, M. W. (1997): Nasal lymphoid tissue intranasll immune-ization and 
Hanaa A. Mansour

compartmentalization of the common mucosal immune system. Immunol. Res. 16: 187- 201.

51. Wu, H. Y.; Nikolova, E. B. ; Beagley, K. W.; Eldridge, J. H. and Russell, M. W. (1997):
Development of the antibodysecreting cells and antigen- specific $\mathrm{T}$ cells in cervical lymph nodes after intranasal immunization. Infect. Immun. 65: 227- 235.

\section{إستجابة بعض الأنسجة للتطعيم عن طريق الأنف: دراسة مناعيةـ

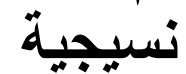

هناء عبد الفتاح السيد منصور 
شعبة الفارماكولوجي (وحدة الميكروبيولوجيا الطبية و المناعة) الهيئة القومية للرقابة و البحوث الدوائية.

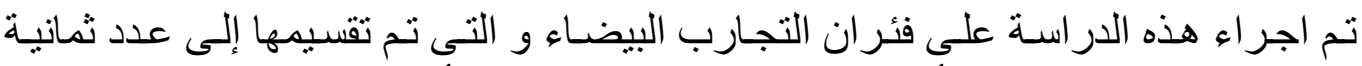

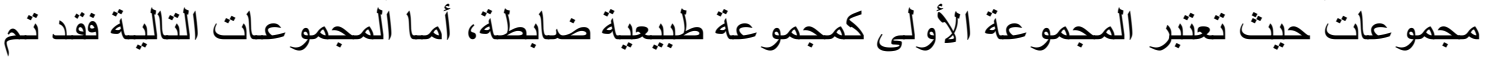

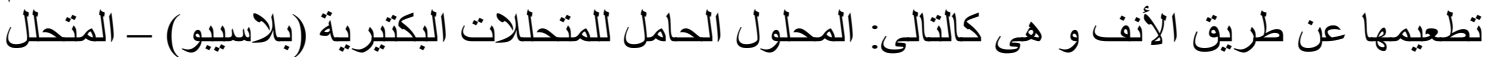

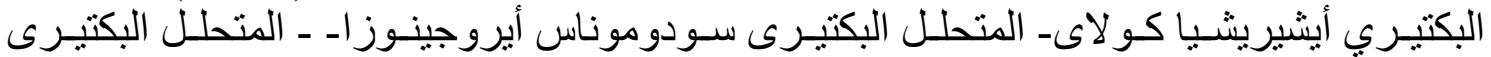

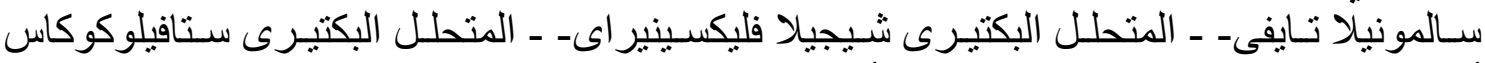

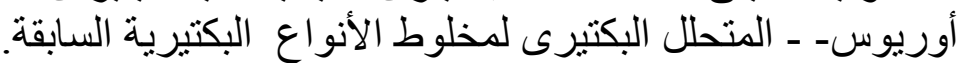

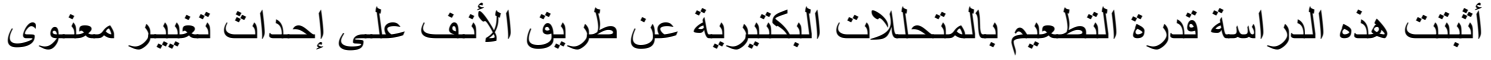

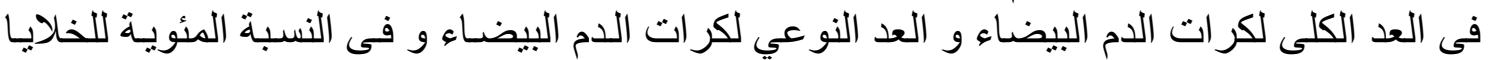

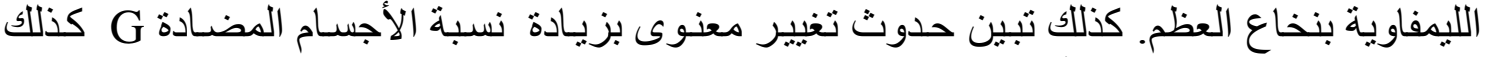

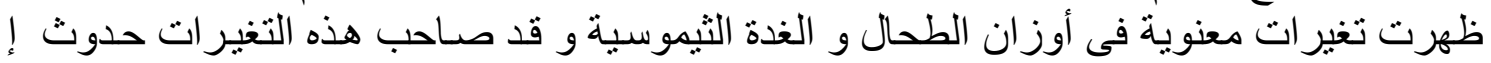

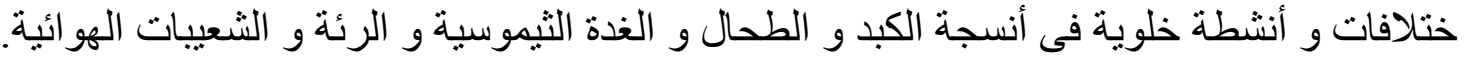

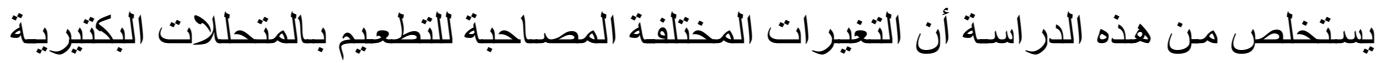
عن طريق الأنف يرشح هذه التطعيمات لأستخدامها كوسيلة مناسبة لتحفيز الجهاز المناعى. 